\title{
Survival of Ralstonia solanacearum Biovar 2, the Causative Agent of Potato Brown Rot, in Field and Microcosm Soils in Temperate Climates
}

\author{
Jan Dirk van Elsas, Pieter Kastelein, Petra van Bekkum, Jean M. van der Wolf, \\ Philippine M. de Vries, and Leo S. van Overbeek
}

IPO-DLO, P.O. Box 16, 6700 AA Wageningen, the Netherlands.

Accepted for publication 31 August 2000.

\begin{abstract}
van Elsas, J. D., Kastelein, P., van Bekkum, P., van der Wolf, J. M., de Vries, P. M., and van Overbeek, L. S. 2000. Survival of Ralstonia solanacearum Biovar 2, the causative agent of potato brown rot, in field and microcosm soils in temperate climates. Phytopathology 90:1358-1366.

After outbreaks of potato brown rot in three different fields in the Netherlands, the fate of the brown rot pathogen, Ralstonia solanacearum biovar 2, was monitored in soil by immunofluorescence colony staining (IFC) supported by $R$. solanacearum division- 2 specific polymerase chain reaction. In selected areas of all fields, the $R$. solanacearum population densities were initially on the order $10^{4}$ to $10^{6}$ per $\mathrm{g}$ of topsoil. These population densities then declined progressively over time. In two fields, however, the pathogen persisted for periods of 10 to 12 months. The survival of a selected $R$. solanacearum biovar 2 isolate, strain 1609, in three soils, a loamy sand and two different silt loam soils, was further studied in soil microcosm experiments. The effects of temperature and soil moisture content were assessed. At 12 or 15 and $20^{\circ} \mathrm{C}$, a gradual

decline of the population densities was observed in all three soils, from the established $10^{5}$ to $10^{6} \mathrm{CFU} \mathrm{\textrm {g } ^ { - 1 }}$ of dry soil to significantly reduced levels, occasionally bordering the limit of detection $\left(10^{2} \mathrm{CFU} \mathrm{g} \mathrm{g}^{-1}\right.$ of dry soil), in periods of approximately 90 to 210 days. Soil type affected the rate of population decline at $20^{\circ} \mathrm{C}$, with the greatest decline occurring in loamy sand soil. In all three soils, the survival of IFCdetectable $R$. solanacearum 1609 cells at $4^{\circ} \mathrm{C}$ was severely impaired, reflected in an accelerated decline of CFU counts, to undetectable numbers. Moreover, indications were found for the occurrence of viable but nonculturable strain 1609 cells in the loamy sand as well as in one silt loam soil under these conditions. In addition, a single freezing-thawing cycle caused a significant additional reduction of the culturable $R$. solanacearum 1609 populations in the three soils, though detectable populations remained. Moderate soil moisture fluctuations of approximately pF 2 did not affect the survival of $R$. solanacearum 1609 in soil. Severe drought, however, drastically reduced the populations of strain $1609 \mathrm{CFU}$ in all three soils.
\end{abstract}

In recent years, evidence has been accumulating that Ralstonia solanacearum, the causative agent of bacterial wilt in potatoes $(2,14)$, may have established itself in the ecosystem, including agricultural soils, of several west European countries $(7,18,29,41)$. Out of the currently known $R$. solanacearum biovars, biovar 2 (race 3) appears to be the organism responsible for most outbreaks of potato brown rot in temperate climates. Biovar 2 is a genetically homogeneous group of organisms $(33,35)$. If this organism, which has long been thought to be typically adapted to tropical climates, can adapt to and persist in soil habitats under temperate climate conditions, local potato cropping practices may be severely affected $(18,29)$.

In practice, there are several ways $R$. solanacearum can enter soil habitats. First, the organism exudes from infected plant tissue, entering the soil inside a matrix of protective polysaccharide (32). Second, infestation of soil sites by the organism may be brought about via irrigation or surface runoff water. Finally, infested machines used in agriculture may spread the organism over fields. The infestation routes in Europe are not exactly known for each individual case of brown rot, but it is likely that all three mechanisms have played a role in recent field infestations. When entering soil via irrigation or machines, the organism may be in a physiological state that differs from that directly following exudation from plant tissue. In any case, and whatever its initial physiology, $R$. solanacearum must withstand stresses imposed on it by the soil to survive in this habitat and potentially infect new host plants.

Corresponding author: J. D. van Elsas; E-mail address: j.d.vanelsas@plant.wag-ur.nl

Publication no. P-2000-1018-02R

(c) 2000 The American Phytopathological Society
Although the persistence of $R$. solanacearum in soils in temperate climates has been the object of several studies, including a range of early reports $(3-5,9-12,20,22-24,31,32)$, there are still uncertainties about its ecological behavior under prevailing factors in these soils. For example, early data suggested that the organism would not survive or compete well in soils of temperate regions (11). Following release from tubers, a time to extinction of only 8 months was recorded in one soil (32). However, $R$. solanacearum survived up to 2 years in bare- or weed-followed soil under temperate conditions (31). In another case, when a potato field abandoned in 1972 was replanted in 1976 with potatoes, wilting symptoms were detected in the new crop, suggesting $R$. solanacearum persisted for 4 years (9). Furthermore, Graham and Lloyd (10) reported that survival of $R$. solanacearum (race 3 ) was enhanced in deeper soil layers, presumably due to less temperature fluctuation, to a lower degree of predation by protozoa or of competition or antagonism by the indigenous microbiota. Olsson (26) found considerable persistence of $R$. solanacearum in Swedish ecosystems following local brown rot outbreaks, but did not elucidate the underlying factors.

Despite the dramatic implications the occurrence of $R$. solanacearum may have for potato crop practices, the organism's survival mechanisms as well as its strategies for persistence under potentially adverse conditions in temperate soils are not well understood. In the majority of previous studies, the population dnamics and physiological responses of the organism in soil have not been addressed with methods that assess both the culturable and the nonculturable (but potentially viable) fractions of the pathogen populations.

To address these points, we monitored the population densities of $R$. solanacearum biovar 2 in soil following the outbreak of brown rot in three potato fields in the Netherlands. We selected an 
aggressive $R$. solanacearum biovar 2 isolate, strain 1609, and performed microcosm experiments to assess its response to typical conditions in Dutch soils. The physiological response of the organism to low temperatures in soil, and its potential to convert to the viable but nonculturable (VBNC) state, are highlighted.

\section{MATERIALS AND METHODS}

Strains and preparation of inocula. $R$. solanacearum biovar 2 (race 3) strain 1609 was used as the model organism for studies on survival and persistence in soil. Several other $R$. solanacearum biovar 2 isolates were obtained from infested fields during this study, and seven were completely characterized and identified as typical biovar 2 strains. These were labeled strains 1804 to 1809 and M1. Strain 1609 was recently isolated from Solanum tuberosum 'Bartina' by the Dutch plant protection service. This strain was tested for its aggressiveness on tomatoes, resulting in the wilting of $100 \%$ (four of four plants) of tomato plants in up to 2 weeks. Strain 1609 was kept frozen in $20 \%$ glycerol at $-80^{\circ} \mathrm{C}$.

For introduction into soil, strain 1609 was grown with shaking (100 rpm) in $0.1 \times$ tryptic soy broth (TSB) $(10 \%$ strength TSB; Oxoid, Unipath LTD, Basingstoke, UK) supplemented with $0.1 \%$ sucrose, for 2 days at $28^{\circ} \mathrm{C}$. Prior to introduction, cells were harvested by centrifugation $(9,000 \times g$ for $20 \mathrm{~min})$, washed twice in sterile $\mathrm{H}_{2} \mathrm{O}$, and the resulting cell suspensions diluted in order to establish cell densities on the order of $10^{7}$ cells $\mathrm{ml}^{-1}$. For introduction into one soil (ILS), strain 1609 was cultured using surface-sterilized grated potato tuber tissue as the substrate. After incubation at $28^{\circ} \mathrm{C}$ for 1 week bacterial cells were separated from the mash by passage through cheesecloth, washed twice in sterile water, and inoculum densities of approximately $10^{6} \mathrm{ml}^{-1}$ established. Cell densities were determined by direct microscopy with a common counting chamber, and confirmed via dilution plating on $0.1 \times$ TSB supplemented with $1.5 \%$ agar $(0.1 \times$ TSBA $)$.

Monitoring the fate of $R$. solanacearum in experimental field sites. Three different experimental fields, denoted M, I, and $\mathrm{H}$ were selected. These fields contained, respectively, silt loam soils of neutral $\mathrm{pH}$ and low (2 to $2.5 \%$ ) organic matter content (M and $\mathrm{H}$ silt loams, MSL and HSL), and a loamy sand soil (I loamy sand, ILS) of relatively high organic matter content (4\%) and low $\mathrm{pH}(\mathrm{pH}-\mathrm{KCl} 5.2$ to 5.5). These fields were selected because maturing potato plants with wilting symptoms were found during the 1997 (MSL and ILS) and 1998 (HSL) growing seasons. In accordance with Dutch national regulations, the fields were treated with the herbicide Roundup to eliminate the crops. From the first report of the pathogen (but after treatment with Roundup), bulk soil from the fields was regularly sampled and analyzed to assess the dynamics of the $R$. solanacearum population densities over a defined time period following infestation. Monitoring was continued for several samplings after none of the samples yielded positive results.

The MSL and ILS fields were sampled following a division of the fields into plots of $2 \times 2 \mathrm{~m}$ (MSL) or $10 \times 10 \mathrm{~m}$ (ILS). Per plot, five to eight replicate topsoil (0 to $10 \mathrm{~cm}$; sample size approximately $50 \mathrm{~g}$ ) samples were combined to yield one or two replicate composite samples. In the first sampling, at least 15 plots were sampled per field. In all later samplings, the same five ILS or six MSL plots were used. These plots were selected on the basis of high levels of $R$. solanacearum. The data were used throughout to describe the organism's population dynamics. The HSL soil was sampled with a focus on two plots where the severity of brown rot symptoms was highest (disease indices of 16 and $23 \%$, respectively). In these two plots, triplicate samples were obtained both from the topsoil and from deeper (30 to $40 \mathrm{~cm}$ and 60 to $70 \mathrm{~cm}$ ) layers. When available, runoff water $(50 \mathrm{ml})$ was collected using a sterile pipette, in triplicate, from the surface of the two selected plots. All samples were taken to the laboratory and processed within $24 \mathrm{~h}$ to assess $R$. solanacearum CFU num- bers by immunofluorescence colony staining (IFC) backed up by $R$. solanacearum-specific polymerase chain reaction (PCR).

Soils for microcosm studies. Three soils belonging to two textural classes were selected for survival studies in soil microcosms. These textural classes are representative of major potato growing areas in the Netherlands. All three soils were freshly collected prior to the experiments. ILS was a loamy sand soil with high organic matter content $(4 \%)$ and a relatively low $\mathrm{pH}(\mathrm{pH}-$ $\mathrm{KCl} 5.2$ to 5.5). It was obtained from a field in the vicinity of the infested potato field I. MSL soil was a neutral ( $\mathrm{pH}-\mathrm{KCl} 7.1)$ silt loam taken from an uninfested border of the experimental plot $\mathrm{M}$ mentioned above. Flevo silt loam (FSL) was a silt loam obtained from the Flevopolder with approximately $2 \%$ organic matter and a neutral to slightly alkaline $\mathrm{pH}(\mathrm{pH} 7.2$ to 7.4$)$. Regardless of the presence of $R$. solanacearum, all soils contained on the order of $10^{7}$ to $10^{8}$ culturable bacteria per $\mathrm{g}$, as evidenced by dilution plating on $0.1 \times$ TSBA $(8)$.

Microcosms and experimental design. The survival of strain 1609, as affected by soil type, temperature and moisture content, was monitored in the ILS, MSL, and FSL soils. In all three soils, $10^{5}$ to $10^{6}$ washed cells of strain 1609 per gram were introduced by pipetting, establishing a soil moisture content of approximately $70 \%$ of the soil's water holding capacity (WHC), which roughly corresponds to $\mathrm{pF} 2$. The ILS microcosms consisted of replicate PVC cylinders (height $25 \mathrm{~cm}$, diameter $10 \mathrm{~cm}$ ) filled with 2,000 g of inoculated soil. The subsequent experiments with the MSL and FSL soils used smaller microcosms consisting of triplicate plastic containers containing $140 \mathrm{~g}$ of inoculated soil (bulk density about 1.4). All containers were periodically sampled by IFC to assess the $R$. solanacearum strain 1609 CFU. All experiments were carried out in triplicate.

In a first set of experiments, the effect of soil temperature on $R$. solanacearum strain 1609 survival was tested by comparing its population dynamics in microcosms incubated at 4,12 , and $20^{\circ} \mathrm{C}$ $\left(15^{\circ} \mathrm{C}\right.$ for ILS soil). In addition, we assessed the effect of $4^{\circ} \mathrm{C}$ on the physiological status of cells in soil, including the potential occurrence of VBNC.

In a second set of experiments, the effect of soil freezing and thawing on the survival of $R$. solanacearum was studied, as compared with the effects of low $\left(4^{\circ} \mathrm{C}\right)$ temperature. For this purpose, $R$. solanacearum-inoculated soils that had been kept at $4^{\circ} \mathrm{C}$ were either kept at $4^{\circ} \mathrm{C}$ (control) or subjected to one, two, or three cycles of $4^{\circ} \mathrm{C} /-5^{\circ} \mathrm{C}(24 \mathrm{~h}) / 4^{\circ} \mathrm{C}$ or of $4^{\circ} \mathrm{C}-1.5^{\circ} \mathrm{C}(24 \mathrm{~h}$ or until ice crystals formed $) / 4^{\circ} \mathrm{C}$.

In a third experiment, the effects of soil moisture fluctuations on $R$. solanacearum strain 1609 survival were tested, comparing the population dynamics at two moisture contents near field capacity (50 and 70\%, respectively, of the soil's WHC, corresponding to approximately $\mathrm{pF} 2.5$ or 2 ) with those under conditions of severe drought (10 to $15 \%$ of $\mathrm{WHC}$, corresponding to about $\mathrm{pF} 3.5$ ). Additionally, in MSL soil the effect of a high (90\% of WHC) moisture content was also assessed.

Soil sampling and processing. All composite samples obtained regularly from the experimental fields (until several samplings after $R$. solanacearum numbers were below the limit of detection) were homogenized, after which $10 \mathrm{~g}$ subsamples were taken and used directly for the analyses by IFC, selective medium South Africa (SMSA) plating, and PCR. In addition, the runoff water samples collected were homogenized by Vortex-mixing and used for these analyses.

All microcosms were sampled at preset times following the start of the experiments, of approximately 90 to 210 days, or until the samples revealed $R$. solanacearum numbers near or at the limit of detection. The ILS soil microcosms were sampled by carefully removing 25-g samples, which were subsequently homogenized by mixing; 10-g subsamples were then used for the analyses. The MSL and FSL soil microcosms were sampled by directly removing $10-\mathrm{g}$ samples without disturbing the structure of the remaining soil. 
All 10-g soil samples obtained were either used directly, or 1-g aliquots were removed for soil DNA extraction and subsequent PCR analysis. The samples for plating assays were placed in 250-ml shake flasks containing $95 \mathrm{ml}$ of $0.1 \%$ sodium pyrophosphate and $10 \mathrm{~g}$ of gravel ( 2 to $4 \mathrm{~mm}$ diameter). Flasks were shaken for $20 \mathrm{~min}$ at $280 \mathrm{rpm}$, after which aliquots were removed for IFC or plating onto SMSA. Runoff water samples were shaken and aliquotted similarly.

Determination of $R$. solanacearum $\mathrm{CFU}$ and cell numbers from soils. IFC and, on some occasions, plating onto SMSA (6) were used to enumerate the $R$. solanacearum CFU per gram of soil. The specific detection of $R$. solanacearum by IFC has been recently validated (37), and this validation was further supported by data obtained in this study. Detection was performed according to the protocol described (37) by overnight staining with 1:50 diluted polyclonal fluorescein isothiocyanate (FITC)-conjugated anti- $R$. solanacearum antiserum (AS9527). Colonies appearing as characteristic dark-green disk shapes were detected with a Wild microscope with incident UV light at low $(\times 25)$ magnification. Randomly picked colonies were regularly checked by direct colony PCR by $R$. solanacearum division- 2 specific primers.

On occasion, $R$. solanacearum was presumptively detected from soil by plating serial 10 -fold dilutions of soil suspensions

A

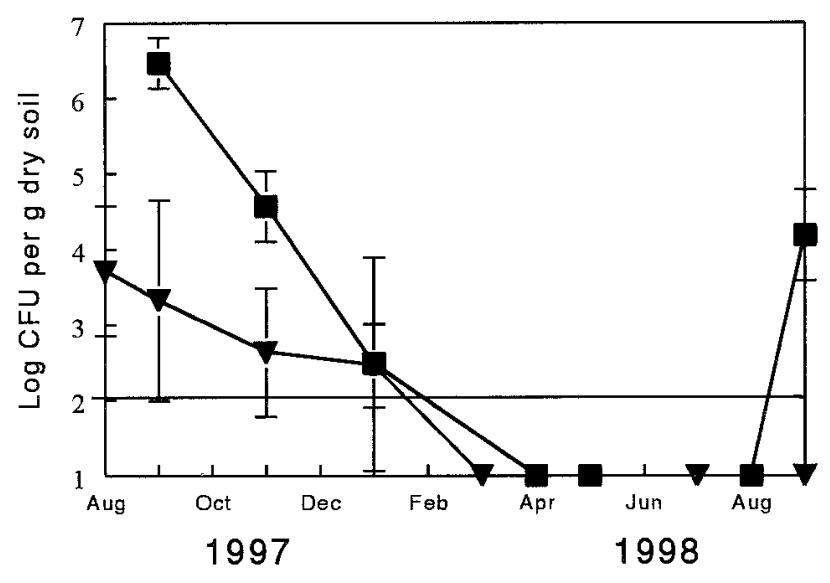

B

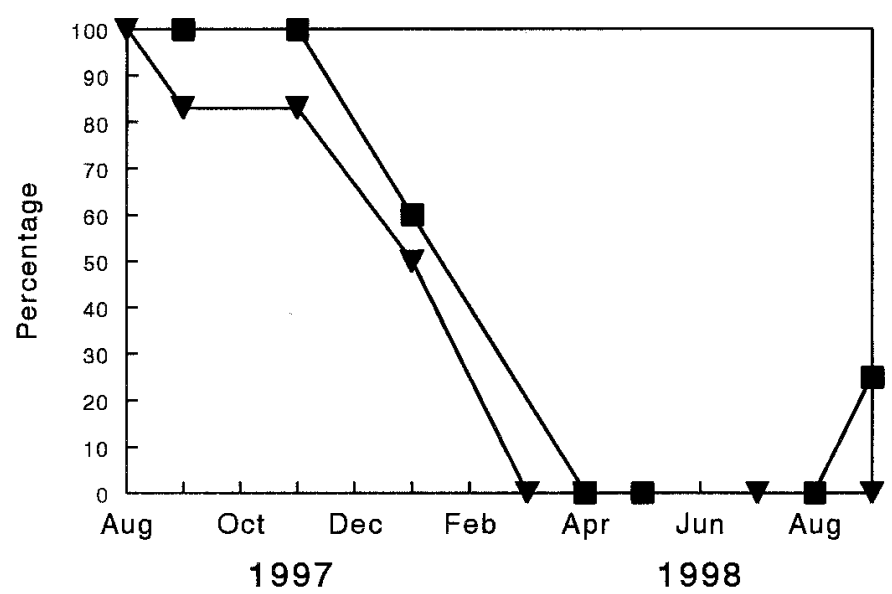

Fig. 1. Persistence of Ralstonia solanacearum in the field. $\mathrm{M}$ silt loam $=\mathbf{\nabla}$; $\mathrm{I}$ loamy sand $=\mathbf{D}$. A, Average immunofluorescence colony staining counts per gram of dry soil. Variation indicated by error bars or within dimensions of the symbols. The limit of detection is indicated by a horizontal line at log 2 . Values below detection were arbitrarily placed at $\log 1$. B, Percentage of plots in which $R$. solanacearum was found. onto the surface of SMSA plates and incubating the plates at $27^{\circ} \mathrm{C}$ for $48 \mathrm{~h}$. Typical (smooth, red) colonies were verified by PCR. To confirm identity, a selection of isolates was obtained from IFC plates from all three experimental fields. These isolates were subjected to identification procedures.

The total numbers of $R$. solanacearum cells were determined via direct immunofluorescence (IF) of soil suspensions on filters as described (28) with the $R$. solanacearum specific polyclonal antibody (37). A 1:50 dilution of the FITC-conjugated anti- $R$. solanacearum antiserum was used. The direct viable count (DVC) was performed in accordance with Kogure et al. (21), using $0.025 \%$ yeast extract and $20 \mu \mathrm{g} \mathrm{ml}^{-1}$ of nalidixic acid (overnight, $20^{\circ} \mathrm{C}$ ). To confer specificity, DVC was combined with specific antibody staining as applied by Heijnen et al. (15).

Soil DNA extractions. To determine the presence or absence of $R$. solanacearum in the field soil samples, specific PCR was performed on total microbial DNA obtained from the ILS, MSL and HSL soils. A direct soil DNA extraction protocol (38) was used on 1-g soil samples, which allowed the flexible use of purification steps until PCR amplifiable DNA was obtained. The final extracts were checked for yield, molecular size, and purity of the DNA by electrophoretic separation in $0.8 \%$ agarose gels. All soils analyzed yielded 10 to $25 \mu \mathrm{g}$ PCR amplifiable DNA, of 10 to $40 \mathrm{~kb}^{-1} \mathrm{~g}$, dry soil.

PCR detection of $\boldsymbol{R}$. solanacearum. For detection of $R$. solanacearum biovar 2, the specific $16 \mathrm{~S}$ rDNA-based primers described by Boudazin et al. (1) (p122f: GTC CGG AAA GAA ATC GCT TC and p123r: GCG GGA CTT AAC CCA ACA TC) were used. These primers recognized all 50 tested strains of division 2 of $R$. solanacearum, which includes biovars 1 and 2, and none of 44 other diverse genera (1; unpublished data). Amplicons of approximately $650 \mathrm{bp}$ were commonly obtained. The PCR reaction mixes consisted of $1 \mu \mathrm{l}$ of target DNA (for soil: 5 to $10 \mathrm{ng}$ of DNA), $200 \mu \mathrm{M}$ of each dNTP, $0.2 \mu \mathrm{M}$ of each primer, $3.7 \mathrm{ng}^{-1} \mathrm{l}^{-1}$ of T4 gene 32 protein, $1 \%$ formamide, $5 \mathrm{U}$ of Taq DNA polymerase Stoffel fragment (Perkin-Elmer, Nieuwerkerk, Netherlands), and $1 \times$ Stoffel buffer (Perkin-Elmer) in a total reaction volume of $50 \mu \mathrm{l}$. PCR was performed in a thermal cycler (PTC200 Peltier, MJ Research, Biozym, Landgraaf, Netherlands), using a hot start (initial melting at $95^{\circ} \mathrm{C} ; 5 \mathrm{~min}$ ), then 35 to 45 cycles of $94^{\circ} \mathrm{C}$ for $20 \mathrm{~s}, 66^{\circ} \mathrm{C}$ for $1 \mathrm{~min}, 72^{\circ} \mathrm{C}$ for $1 \mathrm{~min}$, and a final extension for $10 \mathrm{~min}$ at $72^{\circ} \mathrm{C}$. PCR products were routinely verified by electrophoresis in $1 \%$ agarose gels followed by staining with ethidium bromide.

Characterization of isolates. Selected presumptive $R$. solanacearum isolates verified by division 2 -specific PCR were further characterized by fatty acid methyl ester (FAME) identification, and by their reaction with the $R$. solanacearum-specific $23 \mathrm{~S}$

TABLE 1. Population dynamics of Ralstonia solanacearum biovar 2 after outbreak of potato wilt in $\mathrm{H}$ silt loam field soil in two selected subplots and runoff water

\begin{tabular}{llll}
\hline & & \multicolumn{2}{c}{ Log CFU g $^{-1}$ dry soil or ml $^{-1}$ water $^{\mathrm{b}}$} \\
\cline { 3 - 4 } Period (1998)/day & Soil or water $^{\mathrm{a}}$ & Subplot 1 & Subplot 2 \\
\hline August/7 & Surface & $5.89(0.41)$ & $6.39(0.19)$ \\
October/70 & Surface & $4.62(0.94)$ & $4.72(0.95)$ \\
& Intermediate & $4.53(1.11)$ & $2.72(0.98)$ \\
November/100 & Deep & $3.30(0.65)$ & $2.49(0.69)$ \\
& Surface & $4.16(0.67)$ & $3.21(0.32)$ \\
December/130 & Runoff water & $2.85(0.55)$ & $2.08(0.6)$ \\
& Surface & $3.25(0.74)$ & $2.74(0.5)$ \\
& Intermediate & $3.21(0.98)$ & $2.17(0.32)$ \\
February (1999)/190 & Deep & $2.17(0.53)$ & $1.85(0.14)$ \\
June $(1999) / 300$ & Runoff water & $2.60(0.45)$ & $2.04(0.34)$ \\
L & Surface & $2.44(0.61)$ & $2.57(0.92)$ \\
& Surface & $3.0(0.32)$ & $2.39(0.52)$ \\
\hline
\end{tabular}

a Surface $=0$ to $10 \mathrm{~cm}$ topsoil; Intermediate $=30$ to $40 \mathrm{~cm}$; Deep $=60$ to $70 \mathrm{~cm}$.

b Standard deviations over triplicates are in parentheses. 
rDNA based probe RsolB, using whole cell hybridization (42). Furthermore, their colony morphology on SMSA was assessed and they were tested for pathogenicity on tomato 'Moneymaker', as well as by an eggplant leaf infiltration test (34).

Statistical treatment of data. Statistics behind the field monitoring are described above. All experiments in microcosms were executed in triplicate. Analysis of variance was carried out on the (log-transformed) data with the statistical program Genstat-5 (release 4.1, Rothamsted Experimental Station, Harpenden, UK). Differences between treatments or variables were considered significant at $P<0.05$. Trends in the decline rates observed in the microcosm studies were compared by linear regression analysis.

\section{RESULTS}

Evaluation of IFC for detection of $\boldsymbol{R}$. solanacearum biovar 2 in soils. In initial SMSA (6) platings from soil, several colonies were observed that could not be identified as $R$. solanacearum division 2 via specific PCR. FAME analysis confirmed that these colonies were not $R$. solanacearum. The feasibility of specific detection of $R$. solanacearum from soil by the IFC method, originally developed for detection of Erwinia spp. (40) was therefore assessed. Application of IFC to pure cultures of different $R$. solanacearum biovar 2 strains yielded expected numbers of typical disk-shaped dark-green colonies (data not shown), suggesting that IFC is a useful method for detecting this pathogen in soil.

An assessment of the population density of $R$. solanacearum strain 1609 in ILS soil kept at $20^{\circ} \mathrm{C}$ by IFC and SMSA dilution plating showed that both methods yielded colony numbers in the same order of magnitude (on SMSA, presumptive $R$. solanacearum colonies were assessed, as confirmed by colony PCR). The limit of detection of IFC was approximately $10^{2} \mathrm{CFU} / \mathrm{g}$ of dry soil, which was similar to that of SMSA plating (37).

A random subset of green fluorescent colonies obtained from infested soils that showed typical disk-shape morphology in IFC, presumably representing $R$. solanacearum, was tested through PCR of colony material (36) with the selected primers. All colonies presumptively identified as $R$. solanacearum yielded a PCR product of expected size, indicating they belonged to $R$. solanacearum division 2. Furthermore, aggressiveness on tomatoes was confirmed for a selection of these strains. Because these data indicated that IFC with the specific antiserum was a reliable method to detect $R$. solanacearum biovar 2 in soil, this method was selected for the detection and enumeration of $R$. solanacearum in the field as well as in microcosms.

Persistence of $\boldsymbol{R}$. solanacearum in naturally infested fields. Three fields on which bacterial wilt was detected in potato stands, i.e., MSL, ILS, and HSL, were selected in order to monitor the survival of $R$. solanacearum over time. The three fields had been under a common agricultural rotation, in which potatoes were grown every fourth year.

Persistence in MSL soil. Shortly after the outbreak in 1997, the average $R$. solanacearum population density over the MSL field was on the order of $10^{4} \mathrm{CFU} / \mathrm{g}$ dry soil (Fig. 1A). The population tended to decrease over a 5-month fallow period (from August 1997 to January 1998) to levels slightly above the IFC detection limit $\left(10^{2} \mathrm{CFU} \mathrm{g}^{-1}\right.$ of dry soil). Over this period, the average topsoil $(10 \mathrm{~cm})$ temperature dropped from approximately 20 to $4^{\circ} \mathrm{C}$ (19). Following this period, the pathogen remained below detection by IFC. The number of plots with confirmed presence of $R$. solanacearum followed a similar trend (Fig. 1B). Whereas $R$. solanacearum division 2 specific PCR amplifications of the first two soil DNA samples produced specific bands (Fig. 2, one timepoint), all amplifications performed with soil DNA obtained in the postwinter period provided negative results.

Persistence in ILS soil. The average $R$. solanacearum numbers encountered in ILS soil were on the order of $10^{6} \mathrm{CFU} \mathrm{g}^{-1}$ dry soil immediately following the outbreak of potato wilt (Fig. 1A). In subsequent samplings, a progressive decline to numbers at or below the detection limit in 5 months (fallow) was observed. Surprisingly, 1 year after the outbreak, the pathogen was again detected in the ILS soil, but at low density and in only $25 \%$ of the samples analyzed (Fig. 1B). A substantial fraction of potato tubers sampled from the field in 1998 (3/6) also contained the pathogen. $R$. solanacearum division 2 specific PCR of soil DNA showed that the pathogen was consistently detectable in the initial period, i.e., the first two samplings (Fig. 2), when the numbers of culturable cells were also high (Fig. 1A). No positive PCR signals, however, were found in any later soil sample, including those obtained after the winter period.

Persistence in HSL soil. In HSL soil, the initial population densities in topsoil layers were on the order of $10^{6} \mathrm{CFU} \mathrm{\textrm {g } ^ { - 1 }}$ of dry soil (Table 1). As in the MSL and ILS field soils, the population declined slowly, to approximately $10^{3} \mathrm{CFU} \mathrm{g^{-1 }}$ soil after approximately 4 months. In the HSL soil plots, the recorded soil temperature dropped from approximately 18 to $5^{\circ} \mathrm{C}$, whereas heavy rainfall resulted in high average soil moisture. Intermediate and deep soil layers (30 to 40 and 60 to $70 \mathrm{~cm}$ deep respectively) also contained readily detectable numbers of $R$. solanacearum CFU, with a smaller relative decline than that noted in HSL topsoil. The average temperatures in these deeper layers remained between 10 and $15^{\circ} \mathrm{C}$. Runoff water taken after torrential rains (November 1998) also showed elevated numbers $\left(10^{2}\right.$ to $\left.10^{3} \mathrm{CFU} \mathrm{ml}{ }^{-1}\right)$ of the pathogen. Ten months after the outbreak, several samples collected from the field still contained $R$. solanacearum, at CFU numbers bordering the limit of detection. As in the other soils, DNA from all samples with $R$. solanacearum CFU counts minimally on the order $10^{3}$ to $10^{4} \mathrm{~g}^{-1}$ of dry soil showed positive PCR amplifications, whereas those with lower CFU counts were negative (Fig. 2).

Confirmation of nature of isolates. Isolates from IFC plates that were presumptively $R$. solanacearum were obtained from all three fields (approximately 8 per field), giving a total of 26 strains. All isolates yielded a band of expected size following PCR amplification with the $R$. solanacearum division 2 specific primers (Fig. 2, selected isolates), and reacted with the Rsolb 23S rDNA probe (42). All produced smooth red colonies on SMSA, which are typical of the aggressive form of $R$. solanacearum biovar 2. FAME analysis revealed that all had the pattern typical for $R$. solanacearum biovar 2. A selected subset of seven isolates, 1804 to 1807 and M1, was pathogenic on tomatoes, causing wilting symptoms

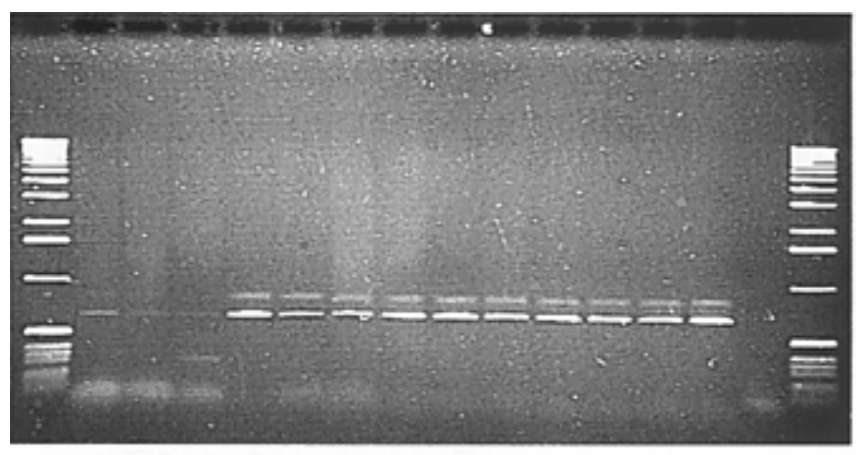

\section{$\begin{array}{llllllllllll}1 & 2 & 3 & 4 & 5 & 6 & 7 & 8 & 91011 & 1213141516\end{array}$}

Fig. 2. Polymerase chain reaction detection of Ralstonia solanacearum in DNA extracted from infested field soils (I loamy sand [ILS], M silt loam [MSL], and H silt loam [HSL]) and field isolates. Lanes 1 and 16, molecular size marker (1-kb ladder); lanes 2 to 7 , six field soil DNA extracts, as indicated (soil, sampling): $2=\mathrm{ILS}, 1 ; 3=\mathrm{ILS}, 2 ; 4=\mathrm{MSL}, 1 ; 5=\mathrm{HSL}, 1$; $6=$ HSL, $2 ; 7=$ HSL, 3 ; lanes 8 to 13 , six bacterial isolates (strains 1804 through 1809) obtained from the field and confirmed as $R$. solanacearum biovar 2; 14, positive control (product of strain 1609); 15, negative (water) control. 


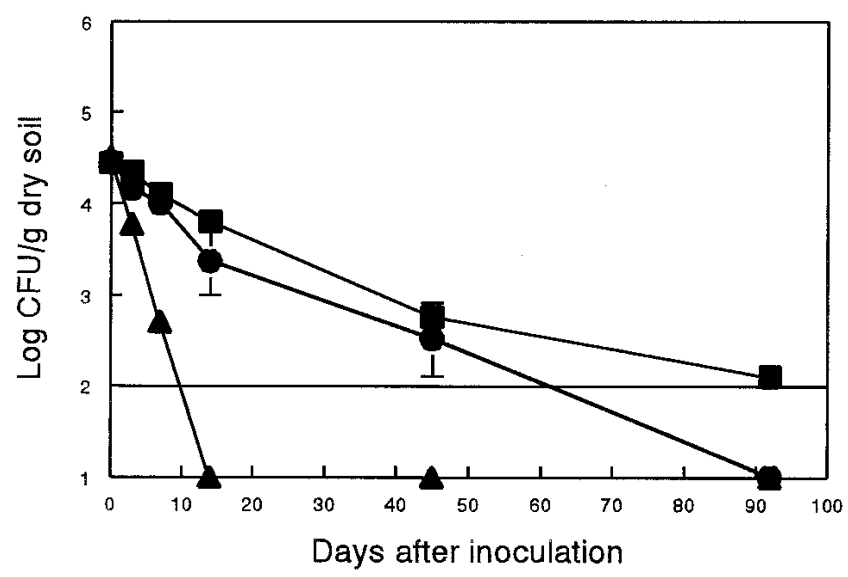

B

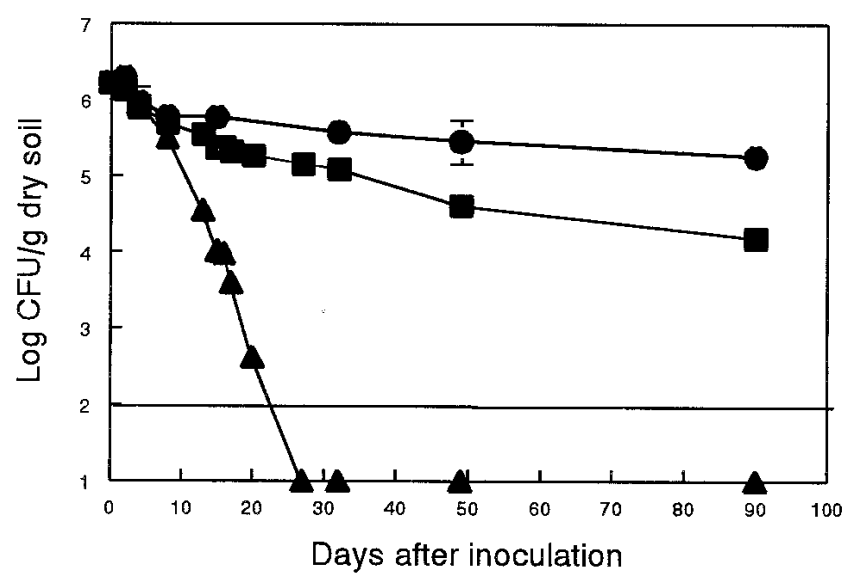

C

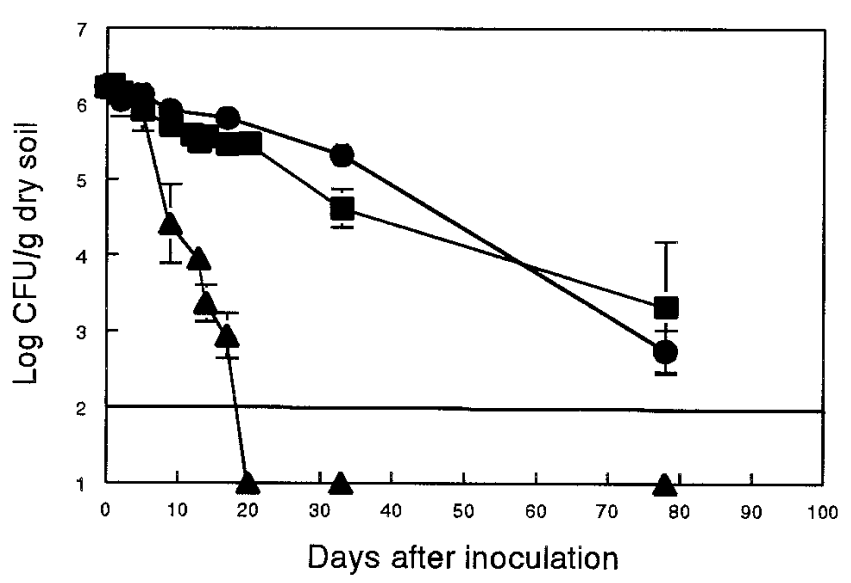

Fig. 3. Effect of temperature on the survival of Ralstonia solanacearum (biovar 2) strain 1609 in different soils in microcosms. A, I loamy sand soil. B, M silt loam soil. C, Flevo silt loam soil. Variation indicated by error bars or within dimensions of the symbols. Limits of detection are indicated by horizontal lines at $\log 2$. Values below detection were arbitrarily placed at $\log$ 1. Log-transformed values in $\mathrm{M}$ silt loam soil after 210 days were 3.15 at $12^{\circ} \mathrm{C}$ and 4.2 at $20^{\circ} \mathrm{C} . \boldsymbol{\Delta}=4^{\circ} \mathrm{C} ; \boldsymbol{\square}=12^{\circ} \mathrm{C}\left(15^{\circ} \mathrm{C}\right.$ for I loamy sand soil $) ; \boldsymbol{O}=$ $20^{\circ} \mathrm{C}$. within 2 weeks of injection. Moreover, these strains showed a positive eggplant leaf infiltration test. Taken together, these data showed that the organism detected and enumerated by IFC, and verified by PCR, was $R$. solanacearum biovar 2 .

Population dynamics of $R$. solanacearum strain 1609 in different soils, as affected by soil temperature. We assumed that the abiotic soil factors temperature and soil type were key determinants of $R$. solanacearum survival in (fallow) soil. Therefore, we tested the survival of the selected strain 1609 in a loamy sand, ILS, compared with two silt loam soils (MSL and FSL), in a range of experiments.

First, the effect of temperature on the survival of $R$. solanacearum strain 1609 in soil kept at approximately $70 \%$ of its WHC was assessed. In all three soils $R$. solanacearum 1609 survived for extended periods of time, approximately 90 days, at the two high temperatures 12 or $15^{\circ} \mathrm{C}$ and $20^{\circ} \mathrm{C}$, showing gradual declines of population sizes (Fig. 3). Even after 210 days (Fig. 3B), popula-

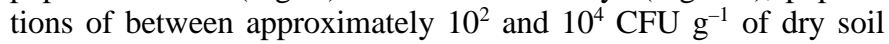
were still present in MSL soil at both temperatures. With one exception (that is, the survival in MSL soil at $20^{\circ} \mathrm{C}$ was superior to that at $12^{\circ} \mathrm{C}$ ), there was no significant difference between the survival rates at these two temperatures. On the other hand, at $4^{\circ} \mathrm{C}$ a rapid and significant decline in the numbers of strain 1609 was noted in all three soils, as culturable CFU were no longer detected after 14 to 28 days of incubation (Fig. 3).

At $20^{\circ} \mathrm{C}$, soil type had a significant effect on the survival of strain 1609 , with the highest survival rate recorded in the MSL soil, and the lowest in the ILS soil. At both 12 and $4{ }^{\circ} \mathrm{C}$, the survival rates were similar between the two silt loam soils.

The effect of soil freezing and thawing on the survival of $R$. solanacearum 1609 was assessed in the ILS, MSL, and FSL soils in separate experiments. In all soils, one cycle from 4 to -5 and back to $4^{\circ} \mathrm{C}$ was sufficient to significantly reduce $\mathrm{CFU}$ numbers compared with controls kept at $4^{\circ} \mathrm{C}$ (Fig. 4). Additional freezing and thawing cycles applied to these systems did not result in a greater rate of decline, compared with microcosms kept at $4^{\circ} \mathrm{C}$ (data not shown). As shown in Figure 4, cooling soil down to $-1.5^{\circ} \mathrm{C}$ followed by a temperature increase to $4^{\circ} \mathrm{C}$ resulted in a significant population reduction, but only when ice crystals were detected in soil. This occurred after approximately $24 \mathrm{~h}$ in ILS and FSL soils, but only after 7 days in MSL soil. Increasing the number of freezing-thawing cycles $\left(4 /-1.5 / 4^{\circ} \mathrm{C}\right)$ did not result in

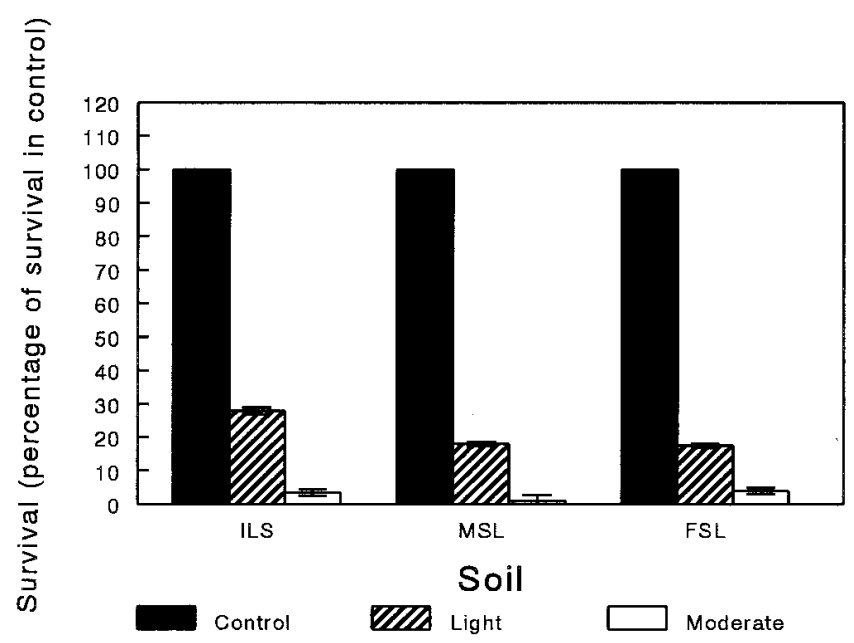

Fig. 4. Survival of Ralstonia solanacearum in three different soils under conditions of light or moderate freezing followed by thawing (respectively $4 /-1.5 / 4^{\circ} \mathrm{C}$ and $\left.4 /-5 / 4^{\circ} \mathrm{C}\right)$ versus the control $\left(4^{\circ} \mathrm{C}\right.$ continuously). Data expressed as the percentage of survival at $4^{\circ} \mathrm{C}$. Results from the former cycle are reported only after visible ice formation (16 h in Flevo silt loam and I loamy sand soils, 7 days in $M$ silt loam soil), as no effects were detectable in the absence of ice crystals. Variation indicated by error bars. 
reductions of $R$. solanacearum population sizes compared with those observed in microcosms kept at $4^{\circ} \mathrm{C}$ following the first cycle (Fig. 4).

Induction of VBNC $R$. solanacearum strain 1609 cells by low temperature. In an experiment with the ILS and FSL soils (representing two soil types), the possible occurrence of VBNC $R$. solanacearum cells in soil at $4^{\circ} \mathrm{C}$ was tested by comparing counts of total specific cells obtained by direct IF, of total substrate-responsive cells (DVC according to Kogure; 21), of strain 1609 specific CFU assessable by SMSA plating and of IFC-detectable CFU (Fig. 5). Whereas the total $R$. solanacearum strain 1609 IF cell count remained relatively constant, at a level of approximately $10^{5}$ to $10^{6}$ per $\mathrm{g}$ of soil, both the IFC and the specific SMSA CFU counts dropped rapidly and significantly in both soils, by 2 to 3 orders of magnitude after 21 days. The IFC counts showed a slightly higher rate of decline than the SMSA counts, suggesting that IFC might be more inhibitory to cold-stressed strain 1609 cells than SMSA plating. On the other hand, the DVC data indicated that a substantial part of the $R$. solanacearum population in soil responded to the substrate by an increase in cell size, i.e., were in a viable state (Fig. 5). On day 21, this VBNC population amounted to $8 \%$ (in ILS) and $>50 \%$ (in FSL) of the total IF detectable populations. The cell numbers thus determined in both cases significantly exceeded the CFU numbers found on either the SMSA or IFC plates (Fig. 5). Using these combined methods, evidence was found for the occurrence of subpopulations of VBNC $R$. solanacearum cells in the two soils investigated.

Effect of soil moisture. The effect of soil moisture level, expressed as a percentage of WHC (10 to 15, 50, and 70\%, corresponding to estimated $\mathrm{pF}$ values of approximately $3.5,2.5$, and 2), on $R$. solanacearum strain 1609 survival was assessed in the ILS, MSL, and FSL soils kept at $20^{\circ} \mathrm{C}$. In all soils, the population dynamics of $R$. solanacearum over time was similar between the 50 and $70 \%$ soil moisture levels (data not shown). On day 35 , an insignificant reduction of population size was noted for MSL and FSL soils at $50 \%$ moisture. Moreover, at this timepoint a 10 -fold higher decrease of CFU numbers in MSL soil kept at $90 \%$ of its WHC was noted compared with that observed in the control kept at $70 \%$ of WHC (data not shown).

In contrast, drying the soil to 10 to $15 \%$ of soil moisture, invariably resulted in rapid and significant reductions of the IFCdetectable $R$. solanacearum strain 1609 populations in the three soils (Fig. 6, results after $24 \mathrm{~h}$ ). The strain 1609 population sizes dropped to below detectable levels within 15 days under this regime (data not shown).

\section{DISCUSSION}

In this study, the fate of culturable $R$. solanacearum biovar 2 cells in field soils following recent infestations of potato crops by this pathogen could be readily followed by a combination of $R$. solanacearum specific IFC and division 2-specific PCR. IFC was based on the microscopical detection of typical dark-green, disk-shaped colonies within the agar that represented $R$. solanacearum (biovar 2). PCR provided additional specificity, based on division 2-specific regions of the $16 \mathrm{~S}$ ribosomal RNA gene (1). The only cross-reacting bacteria, the blood disease bacterium (BDB) of banana and Pseudomonas syzygii (1), did not interfere with this polyphasic approach to $R$. solanacearum detection (37). Thus, the IFC approach, validated by $R$. solanacearumspecific PCR, was deemed reliable to monitor the fate of the pathogen in infested fields. Parallel to this study, Ito et al. (17) also found verification of colonies grown on a semiselective medium by PCR to be promising for monitoring $R$. solanacearum populations in soil.

The current study showed that the persistence of $R$. solanacearum biovar 2 as culturable cells in field soils under temperate climate conditions can be negatively affected by the prevailing soil conditions. An indication of poor persistence in topsoil was first found in the three experimental field sites where IFC counts as well as PCR signals generated by directly extracted soil DNA declined progressively to levels below the respective limits of detection. On the other hand, the pathogen was on occasion still found in significant numbers long after its assumed extinction. It was also detected in surface runoff water. These findings have important implications for potato cropping practices in temperate climate zones, because it is a long-held belief that $R$. solanacearum will rapidly go extinct and thus does not spread. The potential survival of $R$. solanacearum in potato tuber volunteers or other (weedy) plant remains instead of in bulk soil may play a role in the field observations. Indeed, when analyzing both weeds and potato volunteers collected from the ILS and MSL soils, we found evidence for the incidental presence of culturable forms of the pathogen in association with both plant materials (data not shown). In agreement with previous studies $(3,9,11,13,41)$, survival in a culturable form when associated with plant remains may have contributed to the detection of the pathogen 10 to 12 months after the outbreaks of brown rot. Indications for the association of $R$. solanacearum with a range of plants were presented by Dukes

A

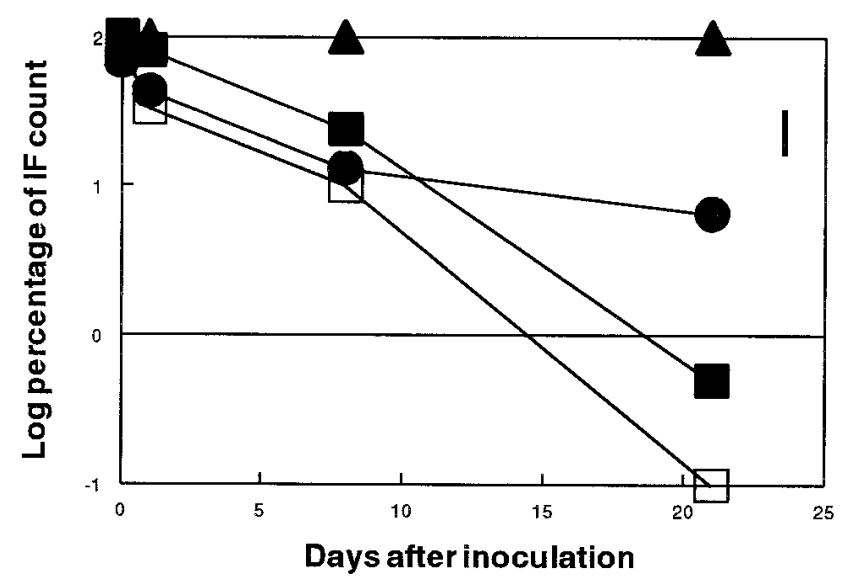

B

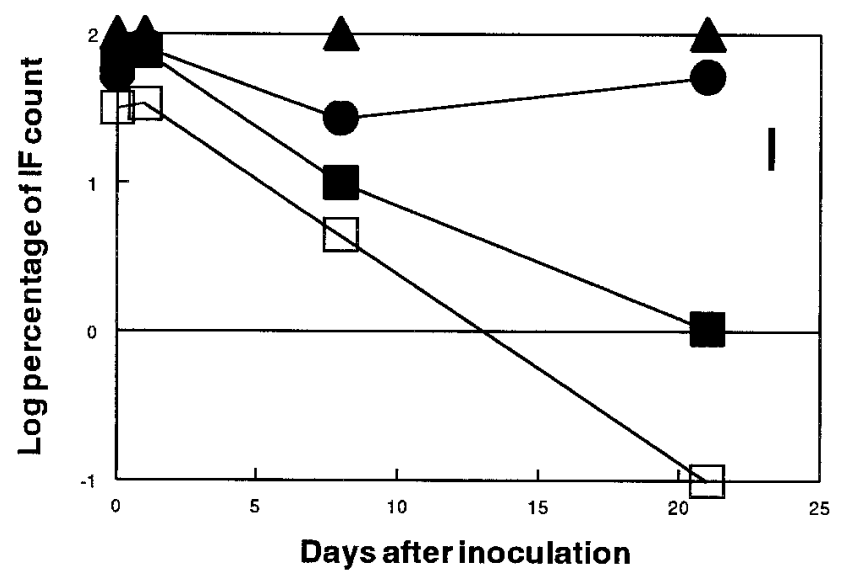

Fig. 5. Appearance of viable-but-nonculturable Ralstonia solanacearum (biovar 2) strain 1609 cells in two different soils placed at $4^{\circ} \mathrm{C}$. A, I loamy sand; B, Flevo silt loam. The log-transformed percentage of the immunofluorescence (IF) count is shown. $\boldsymbol{\Delta}=$ IF (specific immunofluorescence) counts (28); $=$ Direct viable count $(21) ; \mathbf{Q}=R$. solana cearum strain 1609 counts on the semiselective medium SMSA (6); $\square=$ immunofluorescence colony staining counts $(37,40)$. Variation (LSD values, respectively 0.33 for I loamy sand and 0.24 for Flevo silt loam) indicated by vertical bars 
et al. (4), who found heavy losses of tomatoes planted in cleared soils shortly after clearance. Moreover, Moffett and Wood (23) reported that the occurrence of high population densities of $R$. solanacearum correlated with exudation from plant roots, and the numbers depended on the susceptibility of the plants to infection. In contrast, Elphinstone (5) reported that infections of potato groundkeepers and nonaquatic weeds were seldom found. Granada and Sequeira (11) found that $R$. solanacearum CFU numbers in the rhizosphere remained low or undetectable if plants not belonging to the known hosts Solanum tuberosum and Lycopersicon esculentum were infected. On the other hand, in spite of the obvious relevance of certain plants as reservoirs that can promote persistence of $R$. solanacearum, survival directly in the soil or in soil-associated water, possibly in deeper layers, cannot be ruled out as an important factor that determines the fate of $R$. solanacearum following field infestation. This is all the more important for Roundup-treated fields that remain fallow for a considerable period following the outbreak of potato brown rot.

The survival of $R$. solanacearum in bulk soil is theoretically governed by the same external factors that affect the survival of other, nondifferentiating, plant-associated bacteria in soil such as the fluorescent pseudomonads. Van Veen et al. (39) recently reviewed and summarized the available data on bacterial survival as affected by soil factors. Both abiotic (temperature, $\mathrm{pH}$, soil moisture content, and soil type) and biotic factors (presence and activity of grazing protozoa and of antagonistic or competing organisms) affect the survival and physiology of a range of bacteria that invade the soil. There is ample evidence for a relationship between soil textural type (clay content) and pressure from predatory protozoa, as indicated by the finding that finer-textured soils may provide a greater number of sites where bacterial cells are shielded from grazing protozoa $(16,39)$.

The extent to which these factors affect survival can vary and the ultimate effect depends on the physiological and physical requirements for survival of the different bacterial types, as well as on interactions between the various factors acting in the habitat. For example, the survival of $R$. solanacearum race 2 was enhanced by high water content in soil, whereas under such highwater conditions there was no discernable effect of soil type (27). Factors affecting survival in soil may, thus, be intertwined, and the responses of the bacterial populations studied will depend on the relative impact of each factor.
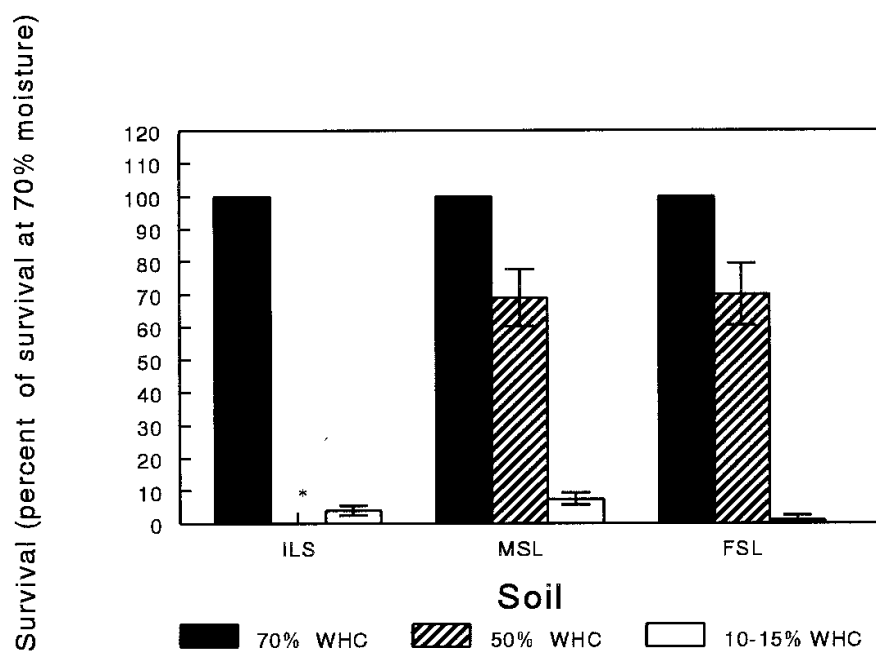

Fig. 6. Effect of different soil moisture contents on the survival of Ralstonia solanacearum (biovar 2) strain 1609 cells in three different soils (I loamy sand [water holding capacity, $\mathrm{WHC}=26 \%$ ], $\mathrm{M}$ silt loam $[\mathrm{WHC}=32 \%$ ] and Flevo silt loam [WHC $=56 \%]$ ). Survival as a percentage of the survival at $70 \%$ moisture is indicated. Data of the 50\% WHC treatments were obtained after 35 days, and data of the 10 to $15 \%$ treatment after 1 day. Variation indicated by error bars. $*=$ not determined.
In this study, the persistence of $R$. solanacearum strain 1609 in soil was dependent on the abiotic conditions temperature and moisture content, as applied in the soil microcosms. As expected, moderate differences in the soil moisture contents (i.e., 50 to $90 \%$ of WHC) did not drastically affect the population dynamics of soil-residing $R$. solanacearum strain 1609 , whereas severe drought resulted in rapid declines of CFU numbers in all soils (Fig. 6). The moderate changes in soil moisture around field capacity will have allowed the presence of differing water films around the cells in soil pores. The small changes in dynamics recorded were most likely related to slight differences in predatory or antagonistic pressure or in the flux of dissolved nutrients induced by the different water films. The effect of severe soil drought on the viability of strain 1609 was likely due to the greatly enhanced matrix tension, related to the reduction of the water films, experienced by the cells. This effect has been described before for other R. solanacearum strains (13,22). For example, Hayward (13) suggested that extreme soil $\mathrm{pF}$ values can result in an accelerated decay of $R$. solanacearum in soil. Schmit and Robert, studying the effect of drought on $R$. solanacearum in organism-clay complexes, attributed the enhanced mortality observed to a physical shrinkage of pore sizes, resulting in a steric lethal effect (30). Any definite inference about the mechanisms underlying the $R$. solanacearum population decline observed in our study, however, would be premature and additional research is warranted.

Temperature had a major effect on $R$. solanacearum strain 1609 persistence in all three soils, with the organism showing slow declines at 12,15 , and $20^{\circ} \mathrm{C}$, but rapid declines of culturable cell numbers when exposed to temperatures of $4^{\circ} \mathrm{C}$ or below. The slow declines at the higher temperatures resemble the behavior of a range of other gram-negative bacteria following their release into soil and have been attributed to abiotic stressors or predation by protozoa $(16,39)$. The population declines at $4^{\circ} \mathrm{C}$ in all three soils, and the concomitant appearance of VBNC cells (which would escape detection via cultivation-based methods) was a major and revealing finding. In contrast, Granada and Sequeira (12) found that $R$. solanacearum in a sandy soil placed at $4^{\circ} \mathrm{C}$ in the laboratory survived for an extended period of time. Their observations, however, were based on CFU counts obtained with semi-selective agar and interference by other bacteria was not clear. Also, VBNC cells were not considered. Our finding of the accelerated decrease of culturability of $R$. solanacearum strain 1609 at $4^{\circ} \mathrm{C}$ can be extended to water systems, where a temperature downshift resulted in a very similar decline in population size (J. D. van Elsas, unpublished data). One explanation for the lack of substantial growth on the two plating media used might be that these media in themselves were semiselective. Exposure of the cells to $4^{\circ} \mathrm{C}$ might, thus, have introduced an impairment of growth-related functions to such an extent that colony formation on the potentially too stressful media was no longer possible. On the other hand, the temperature downshift may have induced a cellular physiological response similar to that often observed in Vibrio vulnificus when exposed to low temperature in marine environments (25). It is unknown whether the resulting cells can, by any means, revert to culturable forms, but this is certainly a topic for future research. In addition, due to the fact that the IFC or SMSA plating methods will not detect VBNC cells, a reconsideration of current methods to assess the fate of $R$. solanacearum populations in environmental habitats is needed, since bacteria escaping detection might still pose a threat to sensitive crops.

$R$. solanacearum strain 1609 was sensitive to soil freezing and thawing. The correlation between detectable ice-crystal formation and population decline, in particular with the $-1.5^{\circ} \mathrm{C}$ treatments, indicates that direct damage to the membranes of cells exposed to ice crystals is the most likely underlying mechanism. The observation that additional freeze-thaw cycles did not further reduce the $R$. solanacearum population sizes, compared with the densities recorded at $4^{\circ} \mathrm{C}$, might indicate that the remaining cells were lo- 
calized in soil pores where ice formation was not possible or prevalent, as it is likely that at the moderate temperatures applied, ice crystal formation in soil was not the same in all soil pores.

The data obtained in the current study revealed that culturable populations of $R$. solanacearum biovar 2 invariably show declines in field soils under prevailing conditions in temperate climates. They further provide indications for drastic population reducing effects of low temperature as well as drought in three different soils. The detection of subpopulations of VBNC cells in soil at $4^{\circ} \mathrm{C}$ opens up a new avenue for study, as the potential of such cells to revert to healthy and possibly infective cells is unknown.

\section{ACKNOWLEDGMENTS}

This study was supported by the Dutch National Brownrot Programme. Further support was received from the EU-FAIR program (contract PL3632). We thank A. Keijzer-Wolters for help with some experiments; partners of the EU Consortium, M. J. Bailey, Oxford, UK, and J. D. Janse, Dutch Plant Protection Service, Wageningen, Netherlands for fatty acid methyl ester identification courtesy; and A. Trigalet, Toulouse, France, for eggplant leaf infiltration test.

\section{LITERATURE CITED}

1. Boudazin, G., Le Roux, A. C., Josi, K., Labarre, P., and Jouan, B. 1999. Design of division-specific primers of Ralstonia solanacearum and application to the identification of European isolates. Eur. J. Plant Pathol. 105:373-380.

2. Buddenhagen, I., and Kelman, A. 1964. Biological and physiological aspects of bacterial wilt caused by Pseudomonas solanacearum. Ann. Rev. Phytopathol. 2:203-230.

3. Devi, L. R., Menon, M. R., and Aiyer, R. S. 1981. Survival of Pseudomonas solanacearum in soil. Plant Soil 62:169-182.

4. Dukes, P. D., Jenkins, S. F. Jr., Jaworski, C. A., and Morton, D. J. 1965. The identification and persistence of an indigenous race of Pseudomonas solanacearum in a soil in Georgia. Plant Dis. Rep. 49:586-590.

5. Elphinstone, J. G. 1996. Survival and possibilities for extinction of Pseudomonas solanacearum (Smith) Smith in cool climates. Potato Res. 39:403-410.

6. Elphinstone, J. G., Hennessy, J., Wilson, J. K., and Stead, D. 1996. Sensitivity of different methods for the detection of Ralstonia solanacearum in potato tuber extracts. EPPO Bull. 26:663-678.

7. Elphinstone, J. G., Stanford, H. M., and Stead, D. E. 1998. Detection of Ralstonia solanacearum in potato tubers, Solanum dulcamara and associated irrigation water. Pages 133-139 in: Bacterial Wilt Disease. Molecular and Ecological Aspects. P. Prior, C. Allen, and J. Elphinstone, eds. Springer-Verlag, Heidelberg, Germany.

8. Gelsomino, A., Keijzer-Wolters, A. C., Cacco, G., and van Elsas, J. D. 1999. Assessment of bacterial community structure in soil by polymerase chain reaction and denaturing gradient gel electrophoresis. J. Microbiol. Meth. 38:1-15.

9. Graham, J., Jones, D. A., and Lloyd, A. B. 1979. Survival of Pseudomonas solanacearum race 3 in plant debris and in latently infected potato tubers. Phytopathology 69:1100-1103.

10. Graham, J., and Lloyd, A. B. 1979. Survival of potato strain (race 3) of Pseudomonas solanacearum in the deeper soil layers. Aust. J. Agric. Res. 30:489-496.

11. Granada, G. A., and Sequeira, L. 1983. Survival of Pseudomonas solanacearum in soil, rhizosphere and plant roots. Can. J. Microbiol. 29:433440.

12. Granada, G. A., and Sequeira, L. 1983. Survival of Pseudomonas solanacearum at low temperature. Fitopatologia 18:22-24.

13. Hayward, A. C. 1991. Biology and epidemiology of bacterial wilt caused by Pseudomonas solanacearum. Ann. Rev. Phytopathol. 29:65-87.

14. Hayward, A. C., and Hartmann, G. L. 1994. Bacterial wilt. The Disease and Its Causative Agent, Pseudomonas solanacearum. CAB International, Oxon, U.K.

15. Heijnen, C. E., Page, S., and Van Elsas, J. D. 1995. Metabolic activity of Flavobacterium strain P25 during starvation and after introduction into bulk soil and the rhizosphere of wheat. FEMS Microbiol. Ecol. 18:129138.

16. Heijnen, C. E., Van Elsas, J. D., Kuikman, P. J., and Van Veen, J. A. 1988. Dynamics of Rhizobium leguminosarum biovar trifolii introduced into soil: The effect of bentonite clay on predation by protozoa. Soil Biol. Biochem. 20:483-488.

17. Ito, S., Ushijima, Y., Fujii, T., Tanaka, S., Kameya-Iwaki, M., Yoshiwara, S., and Kishi, F. 1998. Detection of viable cells of Ralstonia solana- cearum in soil using a semiselective medium and a PCR technique. J. Phytopathol. 146:379-384.

18. Janse, J. D., Araluppen, F. A. X., Schans, J., Wenneker, M., and Westerhuis, W. 1998. Experiences with bacterial brown rot Ralstonia solanacearum biovar 2, race 3 in the Netherlands. Pages 146-152 in: Bacterial Wilt Disease: Molecular and Ecological Aspects. P. Prior, C. Allen, and J. Elphinstone, eds. Springer-Verlag, Heidelberg, Germany.

19. Kastelein, P., Van Overbeek, L. S., Van der Wolf, J. M., and van Elsas, J. D. 1999. Populatiedynamica van Ralstonia solanacearum, de verwekker van bruinrot in aardappel. Aardappelwereld Maart 99, nr. 3:28-31.

20. Keshwal, R. L. 1976. Survival in the soil and virulence of Pseudomonas solanacearum. In: Proc. Int. Plan. Conf. on Ecol. and Control of Bacterial Wilt caused by Pseudomonas solanacearum. L. Sequera, and A. Kelman, eds. Raleigh, NC.

21. Kogure, K., Simidu, U., and Taga, N. 1979. A tentative direct microscopic method for counting living marine bacteria. Can. J. Microbiol. 25:415-420.

22. Moffett, M. L., Giles, J. E., and Wood, B.A. 1983. Survival of Pseudomonas solanacearum biovars 2 and 3 in soil: effect of moisture and soil type. Soil Biol. Biochem. 15:587-591.

23. Moffett, M. L., and Wood, B. A. 1984. Populations of Pseudomonas solanacearum biovar 3 in a naturally infested soil. Soil Biol. Biochem. 16:57-61.

24. Nesmith, W. C., and Jenkins, S. F., Jr. 1983. Survival of Pseudomonas solanacearum in selected North Carolina soils. Phytopathology 73:13001304.

25. Oliver, J. D. 1999. Problems in detecting dormant (VBNC) cells, and the role of DNA elements in this response. Pages 1-15 in: Tracking Genetically-Engineered Microorganisms. J. K. Jansson, J. D. van Elsas, and M. J. Bailey, eds. Landes Bioscience, Georgetown, TX.

26. Olsson, K. 1976. Experience of brown rot caused by Pseudomonas solanacearum (Smith) Smith in Sweden. EPPO Bull. 6:199-207.

27. Pereira, L. V., and Normando, M. C. S. 1993. Sobrevivencia de Pseudomonas solanacearum raca 2 em solos de terra-firme do Estado de Amazonas. Fitopatol. Bras. 18:137-142.

28. Postma, J., Van Elsas, J. D., Govaert, J. M., and Van Veen, J. A. 1988. The dynamics of Rhizobium leguminosarum biovar trifolii introduced into soil as determined by immunofluorescence and selective plating techniques. FEMS Microbiol. Ecol. 53:251-260.

29. Prior, P., Allen, C., and Elphinstone, J. 1998. Bacterial wilt disease: Molecular and Ecological Aspects. Springer-Verlag, Berlin.

30. Schmit, J., and Robert, M. 1984. Action des argiles sur la survie d'une bacterie phytopathogene Pseudomonas solanacearum E.F.S.C.R. Acad. Sci. Paris t. 299, Serie II, 11:733-738.

31. Shamsuddin, N., Lloyd, A. B., and Graham, J. 1979. Survival of the potato strain of Pseudomonas solanacearum in soil. J. Austr. Inst. Agric. Sci. 44:212-215.

32. Shekawat, G. S., and Perombelon, M. C. M. 1991. Factors affecting survival in soil and virulence of Pseudomonas solanacearum. Z. Pflanzenk. u. Pflanzenschutz 98:258-267.

33. Smith, J. J., Offord, L. C., Holderness, M., and Saddler, G. S. 1995. Genetic diversity of Burkholderia solanacearum (synonym Pseudomonas solanacearum) race 3. Kenya. Appl. Environ. Microbiol. 61: 4263-4268.

34. Trigalet, A., Trigalet-Demery, D., and Feuillade, R. 1998. Aggressiveness of French isolates of Ralstonia solanacearum and their potential use in biocontrol. EPPO Bull. 28:101-107.

35. Van der Wolf, J. M., Bonants, P. J. M., Smith, J. J., Hagenaar, M., Nijhuis, E., Van Beckhoven, J. R. C. M., Saddler, G. S., Trigalet, A., and Feuillade, R. 1998. Genetic diversity of Ralstonia solanacearum race 3 in Western Europe determined by AFLP, RC-PFGE, and Rep-PCR. Pages 44-49 in: Bacterial Wilt Disease: Molecular and Ecological Aspects. P. Prior, C. Allen, and J. Elphinstone, eds. Springer Verlag, Heidelberg, Germany.

36. Van der Wolf, J. M., Van Beckhoven, J. R. C. M., De Vries, P. M., Raaijmakers, J. M., Bakker, P. A. H. M., Bertheau, Y., and Van Vuurde, J. W. L. 1995. Polymerase chain reaction for verification of fluorescent colonies of Erwinia chrysanthemi and Pseudomonas putida WCS358 in immunofluorescence colony staining. J. Appl. Bacteriol. 79:569-577.

37. Van der Wolf, J. M., Van Bekkum, P. J., Van Elsas, J. D., Nijhuis, E. H., Vriend, S. G. C., and Ruissen, M. A. 1998. Immunofluorescence colony staining and selective enrichment in liquid medium for studying the population dynamics of Ralstonia (Pseudomonas) solanacearum (race 3) in soil. EPPO Bull. 28:71-79.

38. Van Elsas, J. D., Mantynen, V., and Wolters, A. C. 1997. Soil DNA extraction and assessment of the fate of Mycobacterium chlorophenolicum strain PCP-1 in different soils via 16S ribosomal RNA gene sequence based most-probable-number PCR and immunofluorescence. Biol. Fertil. Soils 24:188-195.

39. Van Veen, J. A., Van Overbeek, L. S., and Van Elsas, J. D. 1997. Fate and activity of microorganisms following release into soil. Microbiol. 
Mol. Biol. Rev. 61:121-135.

40. Van Vuurde, J. W. L., and Van der Wolf, J. M. 1995. Immunofluorescence colony-staining (IFC). Pages 1-19 in: Molecular Microbial Ecology Manual. A. D. L. Akkermans, J. D. van Elsas, and F. J. de Bruiijn, eds. Kluwer Academic Publishers, Dordrecht, Netherlands.

41. Wenneker, M., Verdel, M. S. W., Groeneveld, R. M. W., Kempenaar, C., Van Beuningen, A. R., and Janse, J. D. 1999. Ralstonia (Pseudomonas) solanacearum race 3 (biovar 2) in surface water and natural weed hosts: First report on stinging nettle (Urtica dioica). Eur. J. Plant Pathol. 105:307-315.

42. Wullings, B. A., Van Beuningen, A. R., Janse, J. D., and Akkermans, A D. L. 1998. Detection of Ralstonia solanacearum, which causes brown rot of potato, by fluorescent in situ hybridization with 23S rRNA-targeted probes. Appl. Environ. Microbiol. 64:4546-4554. 